\title{
$A B C B 1$ gene polymorphisms are associated with fatal intoxications involving venlafaxine but not citalopram
}

\author{
Louise Karlsson, Henrik Green, Anna Lena Zackrisson, Finn Bengtsson, I Jakobsen Falk, \\ Björn Carlsson, Johan Ahlner and Fredrik Kugelberg
}

\section{Linköping University Post Print}

\section{Tweet}

N.B.: When citing this work, cite the original article.

The original publication is available at www.springerlink.com:

Louise Karlsson, Henrik Green, Anna Lena Zackrisson, Finn Bengtsson, I Jakobsen Falk, Björn Carlsson, Johan Ahlner and Fredrik Kugelberg, $A B C B 1$ gene polymorphisms are associated with fatal intoxications involving venlafaxine but not citalopram, 2013, International journal of legal medicine (Print), (127), 3, 579-586.

http://dx.doi.org/10.1007/s00414-013-0849-0

Copyright: Springer-Verlag Berlin Heidelberg http://www.springerlink.com/?MUD=MP 


\title{
$A B C B 1$ gene polymorphisms are associated with fatal intoxications involving venlafaxine but not citalopram
}

\author{
L. Karlsson - H. Green - A.L. Zackrisson - F. Bengtsson - I. Jakobsen Falk - \\ B. Carlsson - J. Ahlner - F.C. Kugelberg
}

L. Karlsson - H. Green - F. Bengtsson - I. Jakobsen Falk - B. Carlsson - J. Ahlner - F.C. Kugelberg Division of Drug Research, Clinical Pharmacology, Department of Medical and Health Sciences, Linköping University, Linköping, Sweden

H. Green

Science for Life Laboratory, School of Biotechnology, Division of Gene Technology, Royal Institute of Technology, Stockholm, Sweden

H. Green - A.L. Zackrisson - J. Ahlner - F.C. Kugelberg (corresponding author)

Department of Forensic Genetics and Forensic Toxicology, National Board of Forensic Medicine,

Artillerigatan 12, SE-587 58 Linköping, Sweden

Tel: +46132521 13, Fax: +4613252199

e-mail: fredrik.kugelberg@liu.se 


\begin{abstract}
P-glycoprotein (P-gp), encoded by the $A B C B 1 / M D R 1$ gene, is a drug transporter at the bloodbrain barrier. Several polymorphisms in the $A B C B 1$ gene are known to affect the activity and/or expression of P-gp, thereby influencing the treatment response and toxicity of P-gp substrates like citalopram and venlafaxine. In this study we aimed to investigate the frequency of $A B C B 1$ genotypes in forensic autopsy cases involving these two antidepressants. Further, the distribution of $A B C B 1$ genotypes in deaths related to intoxication was compared to cases not associated to drug intoxication. The study included 228 forensic autopsy cases with different causes and manners of deaths. The $A B C B 1$ single nucleotide polymorphisms (SNPs) G1199A, C1236T, C3435T and G2677T/A for these individuals were determined. The SNPs C1236T and C3435T in venlafaxine positive cases were significantly different between the intoxication cases and non-intoxications. This was not seen for cases involving citalopram, indicating that the effect of genetic variants might be substrate specific. This novel finding should, however, be confirmed in future studies with larger number of cases.
\end{abstract}

\title{
Keywords
}

ABCB1 - Citalopram - Forensic material - Genotype - Postmortem - Venlafaxine 


\section{Introduction}

Postmortem genetic testing (molecular autopsy) has been suggested to provide insights for the interpretation of forensic toxicological results [1-4]. So far, much research has focused on cytochrome $\mathrm{P} 450$ polymorphisms [5-11]. There is now a need for studies on the possible impact of other genetic polymorphisms in forensic autopsy cases.

P-glycoprotein (P-gp), encoded by the $A B C B 1$ gene (also known as $M D R l$ ), is expressed in the endothelium of blood capillaries of the brain (blood-brain barrier; BBB) as well as in the kidneys and the intestine [12]. In order for drugs to exert its effects on the central nervous system (CNS), the drug has to pass the BBB. In the BBB P-gp acts as an efflux pump, which removes its substrates from the brain back into the blood-stream and is capable of extruding drugs with different chemical structures and mechanisms of action, such as antidepressants and antipsychotics [13-20]. Venlafaxine and citalopram are antidepressant drugs and substrates of P-gp. While citalopram belongs to the pharmacodynamic class of selective serotonin reuptake inhibitors (SSRIs), venlafaxine belongs to the class of dual serotonin and noradrenaline reuptake inhibitors (SNRIs) [21].

The $A B C B 1$ gene is located in the human chromosome 7 band $\mathrm{p} 21-21.1$ [22]. Three of the identified single nucleotide polymorphisms (SNPs) in the $A B C B 1$ gene, C3435T, G2677T/A and C1236T are believed to affect the activity and/or expression level of the protein [23-25]. The SNPs have also been associated with altered pharmacokinetics and treatment response [26-28]. Clinical efficiency of antidepressant as well as antipsychotic treatment has been correlated with $A B C B 1$ genetic polymorphisms and substrate properties of several drugs [2831]. To our knowledge, only two studies focusing on the influences of P-gp genotype in postmortem samples have been published $[32,33]$, and so far none on antidepressant drugs. 
Interpretation of postmortem results is not always an easy task [34], and studies focused on the use of genotyping in the forensic case work are warranted. The overall aim of the present study was to investigate the frequency of $A B C B 1$ genotypes in forensic autopsy cases positive for citalopram or venlafaxine. Further, the distribution of $A B C B 1$ genotypes in deaths related to intoxication was compared to cases not associated to drug intoxication.

\section{Methods}

\section{Case selection}

From the Department of Forensic Genetics and Forensic Toxicology in Linköping, Sweden, 228 cases positive for venlafaxine and citalopram (venlafaxine $n=116$, citalopram $n=112$ ) during the toxicological screening were identified and genotyped for $A B C B 1$ SNPs. At the time of the study, the cases were routinely screened for medical substances and ethanol (screening for illegal drugs was only performed upon request). All included cases were classified using International Classification of Disease-9 (ICD-9) codes by the responsible forensic pathologist and divided into intoxications $(n=73$ : suicides, accidents and undetermined; ICD codes E950, E980, E859, E866) and cases not related to drug intoxication ( $n=155$ : non-intoxications; comprising all other causes of death not related to intoxications). Information related to each of the cases (age, gender and other circumstances surrounding death) was provided from the forensic pathology and toxicology databases at the Swedish National Board of Forensic Medicine. Demographic characteristics of the individuals are presented in Table 1. The study was approved by the Regional Ethical Review Board in Linköping, Sweden. 


\section{Toxicological analysis}

Routine screening of a wide range of prescription drugs was determined in femoral blood by capillary gas chromatography (GC) with nitrogen-phosphorus detector. In brief, two different extraction methods were used; an alkaline and a neutral extraction. $1.0 \mathrm{~g}$ of femoral blood was used in both extraction procedures and standard curves, made by adding known amounts of each analyte to drug-free blood, were used for the quantification of drugs [35]. The concentrations of venlafaxine (plus the main metabolite O-desmethylvenlafaxin) and citalopram (plus the main metabolite desmethylcitalopram) were quantified by using this method. Ethanol was determined in blood according to a previously described method [36].

\section{Genotyping for $A B C B 1$}

The following ABCB1 SNPs, G1199A (exon 11, rs2229109), C1236T (exon 12, rs1128503), G2677T/A (exon 21, rs2032582) and C3435T (exon 26, rs 1045642) were identified by PCR and pyrosequncing. In brief, genomic DNA was extracted using King Fischer ML (Thermo Scientific, Vantaa, Finland). Extracted DNA was stored frozen in $-20^{\circ} \mathrm{C}$ until analyzed. PCR and sequencing primers were designed using the PSQAssay Design program (Qiagen, Uppsala, Sweden). PCR primers, sequencing primers and dispensation order for the four SNPs are shown in Table 2. For PCR amplification, the reactions were optimized for $\mathrm{MgCl}_{2}$ concentration $(1.5 \mathrm{mM})$ and annealing temperature $\left(58^{\circ} \mathrm{C}\right)$, and each primer was used at a final concentration of $0.4 \mu \mathrm{M}$. HotStarTaq master mixture (VWR International, Stockholm, Sweden) was used and all reactions were performed on a Mastercycler gradient instrument (Eppendorf, Hamburg, Germany) in a total volume of $12.5 \mu 1$. The four SNPs were analyzed using a PyroMark Q96MD instrument (Qiagen, Uppsala, Sweden) according to the manufactures protocol. 


\section{Statistics}

Statistical differences between groups were calculated using the Fischer's exact test. The distributions of individuals homozygous variant were compared to individuals with the wild type or heterozygous genotype. A P-value $<0.05$ was considered statistically significant. All statistical analysis was performed using StatView ${ }^{\circledR}(\mathrm{SAS} \AA$ Institute, Cary; NC, version 5.0).

\section{Results}

\section{General results}

The study includes 116 cases positive for venlafaxine and 112 cases positive for citalopram. The general characteristics of the cases, analytical results, including concentrations of parent drug and main metabolite, age, sex, cause and manner of death are presented in Table 1 . The material comprised 85 women (37\%) and 143 men (63\%) in total with ages ranging between 18 and 90 years (median 56 years). 91 different substances were detected (median number of drugs were 4; range 1-11). In 39 cases (17\%), venlafaxine or citalopram were the only drug identified and none of the cases were classified as intoxications. The median concentration of venlafaxine was $0.50 \mu \mathrm{g} / \mathrm{g}$ and for the main metabolite O-desmethylvenlafaxine $0.30 \mu \mathrm{g} / \mathrm{g}$. For the citalopram positive cases, the median citalopram concentration was $0.40 \mu \mathrm{g} / \mathrm{g}$ and for the main metabolite desmethylcitalopram $0.10 \mu \mathrm{g} / \mathrm{g}$. Most frequently found drugs in addition to venlafaxine and citalopram are displayed in Table 3. According to the forensic pathologist, the death was related to intoxication (suicide, accident or undetermined) in 73 cases (32\% of all cases). 103 cases were classified as suicides (45\% of all cases) and 35 of these cases were associated with intoxication (34\% of all suicides). The remaining 68 suicide cases were not associated with drug intoxication and hanging was the most frequently cause of death $(n=45)$ followed by drowning $(\mathrm{n}=11)$. The manner of death was considered natural in 51 cases and the 57 cases were classified as accidents. The age, sex, drug and metabolite concentrations in 
relation to other found drugs and cause and manner of death, in all individual cases, are presented in Tables S1 and S2 of the Electronic Supplementary Material.

The genotype frequencies of the $A B C B 1$ gene are given in Table 4 . All the 228 cases, with exception of 3 cases for C1236T, were successfully genotyped for the SNPs (G1199A, C1236T, C2677T/A and C3435T) and did not significantly deviate from the Hardy-Weinberg (HW) equilibrium.

\section{ABCB1 genotypes in intoxication and non-intoxication cases}

The frequencies of the $A B C B 1$ genotypes in intoxications ( $n=73$; comprising suicides, accidents and undetermined intoxication cases) and non-intoxications ( $\mathrm{n}=155$; comprising all other causes of deaths not related to intoxication) are presented in Table 5. The SNPs C1236T and C3435T in venlafaxine positive cases were significantly different between the intoxication cases and the non-intoxication cases $(\mathrm{C} 1236 \mathrm{~T} \mathrm{p}=0.0173 ; \mathrm{C} 3435 \mathrm{~T} \mathrm{p}=0.0074)$. The same trend was observed for G2677T in venlafaxine positive cases, but the comparison did not reach statistically significance $(\mathrm{p}=0.0597)$. Very few individuals positive for venlafaxine were homozygous variants for the SNPs (i.e. individuals 1236TT, 2677TT or 3435TT) in the intoxication cases as compared to the other cases. The genetic variant 1236 and 3435 was significantly different between intoxications and non-intoxications in the whole (citalopram+venlafaxine) material. For the SNP G1199A, a low frequency of the A variant was found and the genotype distribution was not significantly different between intoxications and non-intoxications (no A/A homozygous individuals was found). Very few cases were found to carry the 2677A variant so they were excluded from the analysis. No significantly difference in $A B C B 1$ genotype distribution was seen for the citalopram positive cases. 


\section{Discussion}

Accidental deaths caused by drugs may rely on various causes, including variations in accumulation of drug and therapeutic response. Transport proteins may play an essential role in drug toxicity and efficacy. The knowledge about the distribution of relevant polymorphisms in the gene of e.g. $A B C B 1$ in a population might be valuable information when understanding the cause and manner of deaths in forensic cases. Therefore we investigated the frequencies of four SNPs in the $A B C B 1$ gene to evaluate whether the distribution differed between intoxication and non-intoxication deaths. In the present population we found that the genotype distribution of C1236T, G2677T and C3435T differed in intoxication cases as compared to non-intoxication cases involving venlafaxine.

In humans, $\mathrm{P}$-gp is present in several tissues that are important for drug absorption, distribution and elimination [37]. With regard to the effect of the SNPs on antidepressants few studies are available. Uhr and colleagues published a clinical study of $A B C B 1$ polymorphisms in depressed patients and provided the first evidence that genetic variants account for differences in the clinical efficacy of antidepressants [28]. They found an association between SNPs in $A B C B 1$ and remission in patients taking P-gp substrates (including venlafaxine and citalopram). This is in accordance with our findings that the $A B C B 1$ genotype might influence antidepressant response.

To our knowledge, only two studies with postmortem samples and genotyping for SNPs in $A B C B 1$ have so far been published. The effect of three SNPs (C1236T, G2677T and C3435T) on postmortem digoxin concentration in 112 subjects was studied and they found that the TT-T haplotype allele frequency was higher in the group with high digoxin concentration $(\geq 7$ $\mathrm{nmol} / \mathrm{l}$ ) and that the females might have a higher risk of digoxin intoxication [33]. In a study 
with methadone, no association between the SNPs and methadone concentrations or metabolite concentration was found [32]. In our study we found an association between $A B C B 1$ genotype and drug intoxication in cases involving venlafaxine. This was not seen for cases positive for citalopram, indicating that the effect of genetic variants might be substrate specific.

In the venlafaxine positive cases in the present study, the intoxication group contained no homozygous variant individuals (1236 TT $n=0 ; 2677$ TT $n=1$ and 3435TT $n=4)$. In this forensic material, a carrier homozygous variant for 1236, 2677 and/or 3435 is more likely to have died by suicide not associated with drug intoxication (1236 TT, 73\% suicides; 2677TT, $67 \%$ suicides and $3435 \mathrm{TT} 57 \%$ suicides) and hanging being the most common cause of death. Of the individuals with the TT-TT-TT (1236-2677-3435) haplotype, 70\% (7/10 cases) were suicides (six hangings and one drowning) and none of them were associated with intoxication (suicide, accident or undetermined). If these cases are associated with low therapeutic effects (assuming that they are on medication for depression), severe side effects or a behavioral phenotype leading to the individuals being more prone to suicide, remains to be elucidated. Of the individuals with homozygous variant for one of the SNPs (2677 TT $n=1$ and 3435TT $n=4$ ) in the intoxication group, two were suicides by intoxication, one accident and one undetermined (all cases had venlafaxine concentration at the higher end of the therapeutic range).

The published studies on the effect of $A B C B 1$ polymorphisms on the effects of antidepressants are inconclusive [38-41]. The studies have not been consistently performed and the role of $A B C B 1$ polymorphisms in pharmacokinetics and pharmacodynamics needs to be further studied. Recently, a study reported that polymorphisms in the $A B C B 1$ gene are 
associated with the severity of depression and the effectiveness of the antidepressant escitalopram [42]. The influence of $A B C B 1$ polymorphism on the disposition of the S- and Renantiomers of citalopram in plasma and cerebrospinal fluid (CSF) was examined under steady-state conditions in 15 patients with major depression treated with citalopram. The 2677TT genotype was associated with lower plasma and CSF concentrations than the 2677GT or $2677 \mathrm{GG}$. The $2677 \mathrm{GG} / \mathrm{GT}$ genotype was associated with a better treatment response ( $p=$ 0.001) compared with the 2677TT genotype [43]. Others have not found any associations between SNPs and treatment or drug concentrations. Menu et al. studied whether the response to antidepressants in 117 depressed patients differed in patients with the $3435 \mathrm{CC}$ genotype as compared to patients with the 3435CT and 3435TT genotypes. They found no association between the SNP and antidepressant efficacy or tolerance [44]. In another paper where the associations between $A B C B 1$ polymorphisms and citalopram response and tolerance were studied, no association was found [45].

When dealing with intoxication cases, it is important to consider not only the measured drug concentrations but also possible co-factors that can influence the interpretation of the toxicological results. According to several studies, venlafaxine has a relatively higher fatal toxicity compared with SSRIs and other newer antidepressants [46-49]. Different explanations regarding this finding have been suggested. Launiainen et al. recently reported that fatal venlafaxine poisonings were associated with a high prevalence of drug interactions [50]. This is in line with results previously reported by us [7] and also evident from the present data. The most frequently found prescription drugs, in addition to venlafaxine and citalopram, were zopiclone, paracetamol, propiomazine/dihydropropiomazine, diazepam, alimemazine, nordiazepam and mirtazapine. The present results support the importance of considering adverse drug combinations as one of the major risk factors leading to fatal drug intoxications 
[51,52]. In this context, it should also be noted that among the newer antidepressants, like venlafaxine and citalopram, differences are present both in toxicity and in interaction potential with alcohol [53].

Studies of genetic factors that might influence the risk of intoxication are of value in forensic toxicology. In our postmortem study with 228 cases we found that the genotype distribution of SNPs C1236T and C3435T significantly differed between intoxications and nonintoxications indicating that these polymorphisms might influence the function of $\mathrm{P}$-gp leading to toxicity risk (i.e. high drug concentration in the brain) or unsatisfied therapeutic effect due to low drug concentration in the brain. However, our novel findings should be replicated in future studies with larger groups of cases and with other antidepressants.

\section{Acknowledgments}

The authors express their gratitude to Anita Holmgren for assistance with database processing. This original work has been supported by grants from the National Board of Forensic Medicine in Sweden (HG, ALZ, JA, FCK) and the Swedish Research Council (HG, FB, JA, FCK).

\section{References}

1. Ahlner J, Zackrisson AL, Lindblom B, Bertilsson L (2010) CYP2D6, serotonin and suicide. Pharmacogenomics 11:903-905

2. Andresen H, Augustin C, Streichert T (2012) Toxicogenetics-cytochrome P450 microarray analysis in forensic cases focusing on morphine/codeine and diazepam. Int J Legal Med [Epub ahead of print] doi: 10.1007/s00414-012-0759-6

3. Musshoff F, Stamer UM, Madea B (2010). Pharmacogenetics and forensic toxicology. Forensic Sci Int 203:53-62

4. Sajantila A, Palo JU, Ojanpera I, Davis C, Budowle B (2010) Pharmacogenetics in medicolegal context. Forensic Sci Int 203:44-52 
5. Druid H, Holmgren P, Carlsson B, Ahlner J (1999) Cytochrome P450 2D6 (CYP2D6) genotyping on postmortem blood as a supplementary tool for interpretation of forensic toxicological results. Forensic Sci Int 99:25-34

6. Holmgren P, Carlsson B, Zackrisson AL, Lindblom B, Dahl ML, Scordo MG, Druid H, Ahlner J (2004) Enantioselective analysis of citalopram and its metabolites in postmortem blood and genotyping for CYP2D6 and CYP2C19. J Anal Toxicol 28:94-104

7. Kingbäck M, Karlsson L, Zackrisson AL, Carlsson B, Josefsson M, Bengtsson F, Ahlner J, Kugelberg FC (2012) Influence of CYP2D6 genotype on the disposition of the enantiomers of venlafaxine and its major metabolites in postmortem femoral blood. Forensic Sci Int 214:124134

8. Koski A, Sistonen J, Ojanpera I, Gergov M, Vuori E, Sajantila A (2006) CYP2D6 and CYP2C19 genotypes and amitriptyline metabolite ratios in a series of medicolegal autopsies. Forensic Sci Int 158:177-183

9. Levo A, Koski A, Ojanpera I, Vuori E, Sajantila A (2003) Post-mortem SNP analysis of CYP2D6 gene reveals correlation between genotype and opioid drug (tramadol) metabolite ratios in blood. Forensic Sci Int 135:9-15

10. Wong SH, Wagner MA, Jentzen JM, Schur C, Bjerke J, Gock SB, Chang CC (2003) Pharmacogenomics as an aspect of molecular autopsy for forensic pathology/toxicology: does genotyping CYP 2D6 serve as an adjunct for certifying methadone toxicity? J Forensic Sci 48:1406-1415

11. Zackrisson AL, Lindblom B, Ahlner J (2010) High frequency of occurrence of CYP2D6 gene duplication/multiduplication indicating ultrarapid metabolism among suicide cases. Clin Pharmacol Ther 88:354-359

12. Cordon-Cardo C, O'Brien JP, Casals D, Rittman-Grauer L, Biedler JL, Melamed MR, Bertino JR (1989) Multidrug-resistance gene (P-glycoprotein) is expressed by endothelial cells at blood-brain barrier sites. Proc Natl Acad Sci U S A 86:695-698

13. Doran A, Obach RS, Smith BJ, Hosea NA, Becker S, Callegari E et al (2005) The impact of P-glycoprotein on the disposition of drugs targeted for indications of the central nervous system: evaluation using the MDR1A/1B knockout mouse model. Drug Metab Dispos $33: 165-174$

14. Karlsson L, Hiemke C, Carlsson B, Josefsson M, Ahlner J, Bengtsson F, Schmitt U, Kugelberg FC (2011) Effects on enantiomeric drug disposition and open-field behavior after chronic treatment with venlafaxine in the P-glycoprotein knockout mice model.

Psychopharmacology (Berl) 215:367-377

15. Karlsson L, Schmitt U, Josefsson M, Carlsson B, Ahlner J, Bengtsson F, Kugelberg FC, Hiemke C (2010) Blood-brain barrier penetration of the enantiomers of venlafaxine and its metabolites in mice lacking P-glycoprotein. Eur Neuropsychopharmacol 20:632-640 
16. Kirschbaum KM, Henken S, Hiemke C, Schmitt U (2008) Pharmacodynamic consequences of P-glycoprotein-dependent pharmacokinetics of risperidone and haloperidol in mice. Behav Brain Res 188:298-303

17. Uhr M, Grauer MT (2003) abcb1ab P-glycoprotein is involved in the uptake of citalopram and trimipramine into the brain of mice. J Psychiatr Res 37:179-185

18. Uhr M, Grauer MT, Holsboer F (2003). Differential enhancement of antidepressant penetration into the brain in mice with abcblab (mdrlab) P-glycoprotein gene disruption. Biol Psychiatry 54:840-846

19. Uhr M, Grauer MT, Yassouridis A, Ebinger M (2007) Blood-brain barrier penetration and pharmacokinetics of amitriptyline and its metabolites in p-glycoprotein (abcblab) knock-out mice and controls. J Psychiatr Res 41:179-188

20. Uhr M, Steckler T, Yassouridis A, Holsboer F (2000) Penetration of amitriptyline, but not of fluoxetine, into brain is enhanced in mice with blood-brain barrier deficiency due to mdrla P-glycoprotein gene disruption. Neuropsychopharmacology 22:380-387

21. Vetulani J, Nalepa I (2000) Antidepressants: past, present and future. Eur J Pharmacol 405:351-363

22. Callen DF, Baker E, Simmers RN, Seshadri R, Roninson IB (1987) Localization of the human multiple drug resistance gene, MDR1, to 7q21.1. Hum Genet 77:142-144

23. Hoffmeyer S, Burk O, von Richter O, Arnold HP, Brockmoller J, Johne A, Cascorbi I, Gerloff T, Roots I, Eichelbaum M, Brinkmann U (2000) Functional polymorphisms of the human multidrug-resistance gene: multiple sequence variations and correlation of one allele with P-glycoprotein expression and activity in vivo. Proc Natl Acad Sci U S A 97:3473-3478

24. Kim RB, Leake BF, Choo EF, Dresser GK, Kubba SV, Schwarz UI, Taylor A, Xie HG, McKinsey J, Zhou S, Lan LB, Schuetz JD, Schuetz EG, Wilkinson GR (2001) Identification of functionally variant MDR1 alleles among European Americans and African Americans. Clin Pharmacol Ther 70:189-199

25. Tanabe M, Ieiri I, Nagata N, Inoue K, Ito S, Kanamori Y, Takahashi M, Kurata Y, Kigawa J, Higuchi S, Terakawa N, Otsubo K (2001) Expression of P-glycoprotein in human placenta: relation to genetic polymorphism of the multidrug resistance (MDR)-1 gene. $\mathrm{J}$ Pharmacol Exp Ther 297:1137-1143

26. Evans WE, McLeod HL (2003) Pharmacogenomics - drug disposition, drug targets, and side effects. N Engl J Med 348:538-549

27. Marzolini C, Paus E, Buclin T, Kim RB (2004) Polymorphisms in human MDR1 (Pglycoprotein): recent advances and clinical relevance. Clin Pharmacol Ther 75:13-33

28. Uhr M, Tontsch A, Namendorf C, Ripke S, Lucae S, Ising M, Dose T, Ebinger M, Rosenhagen M, Kohli M, Kloiber S, Salyakina D, Bettecken T, Specht M, Putz B, Binder EB, Muller-Myhsok B, Holsboer F (2008) Polymorphisms in the drug transporter gene ABCB1 predict antidepressant treatment response in depression. Neuron 57:203-209 
29. Bozina N, Kuzman MR, Medved V, Jovanovic N, Sertic J, Hotujac L (2008) Associations between MDR1 gene polymorphisms and schizophrenia and therapeutic response to olanzapine in female schizophrenic patients. J Psychiatr Res 42:89-97

30. Kato M, Fukuda T, Serretti A, Wakeno M, Okugawa G, Ikenaga Y, Hosoi Y, Takekita Y, Mandelli L, Azuma J, Kinoshita T (2008) ABCB1 (MDR1) gene polymorphisms are associated with the clinical response to paroxetine in patients with major depressive disorder. Prog Neuropsychopharmacol Biol Psychiatry 32:398-404

31. Sarginson JE, Lazzeroni LC, Ryan HS, Ershoff BD, Schatzberg AF, Murphy GM, Jr (2010) ABCB1 (MDR1) polymorphisms and antidepressant response in geriatric depression. Pharmacogenet Genomics 20:467-475

32. Buchard A, Linnet K, Johansen SS, Munkholm J, Fregerslev M, Morling N (2010) Postmortem blood concentrations of R- and S-enantiomers of methadone and EDDP in drug users: influence of co-medication and p-glycoprotein genotype. J Forensic Sci 55:457-463

33. Neuvonen AM, Palo JU, Sajantila A (2011) Post-mortem ABCB1 genotyping reveals an elevated toxicity for female digoxin users. Int J Legal Med 125:265-269

34. Drummer OH (2007) Post-mortem toxicology. Forensic Sci Int 165:199-203

35. Druid H, Holmgren P (1997) A compilation of fatal and control concentrations of drugs in postmortem femoral blood. J Forensic Sci 42:79-87

36. Jones AW, Schuberth J (1989) Computer-aided headspace gas chromatography applied to blood-alcohol analysis: importance of online process control. J Forensic Sci 34:1116-1127

37. Endres CJ, Hsiao P, Chung FS, Unadkat JD (2006) The role of transporters in drug interactions. Eur J Pharm Sci 27:501-517

38. Gex-Fabry M, Eap CB, Oneda B, Gervasoni N, Aubry JM, Bondolfi G, Bertschy G (2008) CYP2D6 and ABCB1 genetic variability: influence on paroxetine plasma level and therapeutic response. Ther Drug Monit 30:474-482

39. Laika B, Leucht S, Steimer W (2006) ABCB1 (P-glycoprotein/MDR1) gene G2677T/a sequence variation (polymorphism): lack of association with side effects and therapeutic response in depressed inpatients treated with amitriptyline. Clin Chem 52:893-895

40. Mihaljevic Peles A, Bozina N, Sagud M, Rojnic Kuzman M, Lovric M (2008) MDR1 gene polymorphism: therapeutic response to paroxetine among patients with major depression. Prog Neuropsychopharmacol Biol Psychiatry 32:1439-1444

41. Perlis RH, Fijal B, Dharia S, Heinloth AN, Houston JP (2010) Failure to replicate genetic associations with antidepressant treatment response in duloxetine-treated patients. Biol Psychiatry 67:1110-1113

42. Lin KM, Chiu YF, Tsai IJ, Chen CH, Shen WW, Liu SC, Lu SC, Liu CY, Hsiao MC, Tang HS, Liu SI, Chang LH, Wu CS, Tsou HH, Tsai MH, Chen CY, Wang SM, Kuo HW, 
Hsu YT, Liu YL (2011) ABCB1 gene polymorphisms are associated with the severity of major depressive disorder and its response to escitalopram treatment. Pharmacogenet Genomics 21:163-170

43. Nikisch G, Eap CB, Baumann P (2008) Citalopram enantiomers in plasma and cerebrospinal fluid of $\mathrm{ABCB} 1$ genotyped depressive patients and clinical response: A pilot study. Pharmacol Res 58:344-347

44. Menu P, Gressier F, Verstuyft C, Hardy P, Becquemont L, Corruble E (2009) Antidepressants and $\mathrm{ABCB} 1$ gene $\mathrm{C} 3435 \mathrm{~T}$ functional polymorphism: a naturalistic study. Neuropsychobiology 62:193-197

45. Peters EJ, Slager SL, Kraft JB, Jenkins GD, Reinalda MS, McGrath PJ, Hamilton SP (2008) Pharmacokinetic genes do not influence response or tolerance to citalopram in the STAR*D sample. PLoS One 3, e1872

46. Buckley NA, McManus PR (2002) Fatal toxicity of serotoninergic and other antidepressant drugs: analysis of United Kingdom mortality data. BMJ 325:1332-1333

47. Jönsson A, Holmgren P, Ahlner J (2004) Fatal intoxications in a Swedish forensic autopsy material during 1992-2002. Forensic Sci Int 143:53-59

48. Kelly CA, Dhaun N, Laing WJ, Strachan FE, Good AM, Bateman DN (2004)

Comparative toxicity of citalopram and the newer antidepressants after overdose. J Toxicol Clin Toxicol 42:67-71

49. Whyte IM, Dawson AH, Buckley NA (2003) Relative toxicity of venlafaxine and selective serotonin reuptake inhibitors in overdose compared to tricyclic antidepressants. QJM 96:369-374

50. Launiainen T, Rasanen I, Vuori E, Ojanpera I (2011) Fatal venlafaxine poisonings are associated with a high prevalence of drug interactions. Int J Legal Med 125:349-538

51. Launiainen T, Vuori E, Ojanpera I (2009) Prevalence of adverse drug combinations in a large post-mortem toxicology database. Int J Legal Med 123:109-115

52. Jones AW, Kugelberg FC, Holmgren A, Ahlner J (2011) Drug poisoning deaths in Sweden show a predominance of ethanol in mono-intoxications, adverse drug-alcohol interactions and poly-drug use. Forensic Sci Int 206:43-51

53. Koski A, Vuori E, Ojanpera I (2005) Newer antidepressants: evaluation of fatal toxicity index and interaction with alcohol based on Finnish postmortem data. Int J Legal Med 119:344-348 
Table 1 General information related to the included postmortem cases

\begin{tabular}{|c|c|c|c|c|}
\hline & \multicolumn{2}{|c|}{$\begin{array}{l}\text { Venlafaxine } \\
\text { positive cases }\end{array}$} & \multicolumn{2}{|c|}{$\begin{array}{c}\text { Citalopram } \\
\text { positive cases }\end{array}$} \\
\hline \multicolumn{5}{|l|}{ Sex, n $(\%)$} \\
\hline Male & 75 & $(65 \%)$ & 68 & $(61 \%)$ \\
\hline Female & 41 & $(35 \%)$ & 44 & $(39 \%)$ \\
\hline \multicolumn{5}{|l|}{ Age, years } \\
\hline Median (range) & \multicolumn{2}{|c|}{$50(18-86)$} & \multicolumn{2}{|c|}{$59(19-90)$} \\
\hline \multicolumn{5}{|l|}{ Manner of death ${ }^{\mathrm{a}}, \mathrm{n}(\%)$} \\
\hline Suicide & 58 & $(50 \%)$ & 45 & $(40 \%)$ \\
\hline Accident & 27 & $(23 \%)$ & 30 & $(27 \%)$ \\
\hline Natural & 23 & $(20 \%)$ & 28 & $(25 \%)$ \\
\hline Other & 8 & $(7 \%)$ & 9 & $(8 \%)$ \\
\hline \multicolumn{5}{|l|}{ Intoxications $^{\mathrm{a}}, \mathrm{n}(\%)$} \\
\hline Suicides & 17 & $(47 \%)$ & 18 & $(49 \%)$ \\
\hline Accidents & 16 & $(44 \%)$ & 13 & $(35 \%)$ \\
\hline Undetermined & 3 & $(8 \%)$ & 6 & $(16 \%)$ \\
\hline \multicolumn{5}{|l|}{ Suicides $^{\mathrm{a}}, \mathrm{n}(\%)$} \\
\hline Hanging & 28 & $(48 \%)$ & 17 & $(38 \%)$ \\
\hline Drowning & 6 & $(10 \%)$ & 5 & $(11 \%)$ \\
\hline Intoxication & 17 & $(29 \%)$ & 18 & $(40 \%)$ \\
\hline Other & 7 & $(12 \%)$ & 5 & $(11 \%)$ \\
\hline \multicolumn{5}{|l|}{ Drug concentration, $\mu \mathrm{g} / \mathrm{g}$} \\
\hline Parent: median (range) & \multicolumn{2}{|c|}{$0.50(0.05-6.6)$} & \multicolumn{2}{|c|}{$0.40(0.05-10.5)$} \\
\hline Metabolite: median (range) & \multicolumn{2}{|c|}{$0.30(0-1.6)^{\mathrm{b}}$} & \multicolumn{2}{|c|}{$0.10(0-0.8)^{\mathrm{c}}$} \\
\hline
\end{tabular}

${ }^{\text {a }}$ All included cases were classified by the responsible pathologist using ICD-9 codes.

${ }^{\mathrm{b}} \mathrm{O}$-desmethylvenlafaxine

${ }^{\mathrm{c}}$ Desmethylcitalopram 
Table 2 Primers, sequencing primers and dispensation order for the $A B C B 1$ SNPs

PCR primers

$\begin{array}{lll}\text { SNP } & \text { Forward primer } & \text { Reverse primer }\end{array}$

\begin{tabular}{|c|c|c|}
\hline G1199A & bio*ATTGACAGCTATTCGAAGAGTG & CCTTAACTTCTTTTCGAGATGG \\
\hline $\mathrm{C} 1236 \mathrm{~T}$ & bio*GTCTGTGAATTGCCTTGAAGT & CAGCCACTGTTTCCAACC \\
\hline G2677T/A & bio*GGACAAGCACTGAAAGATAAG & AGGGAGTAACAAAATAACACTGAT \\
\hline C3435T & bio*ACATTGCCTATGGAGACAAC & TAGGCAGTGACTCGATGAAG \\
\hline
\end{tabular}

Sequencing primers

SNP

Sequencing primers

Dispensation order

$\begin{array}{lll}\text { G1199A } & \text { CTTTTCGAGATGGGTAA } & \text { GACTCGAGTGAC } \\ \text { C1236T } & \text { TGCACCTTCAGGTTCA } & \text { TGAGCTCAGAT } \\ \text { G2677T/A } & \text { TTAGTTTGACTCACCTTCC } & \text { GCCAGTCAGCTC } \\ \text { C3435T } & \text { CTTTGCTGCCCTCAC } & \text { CAGAGTCTCT }\end{array}$

*bio: biotinylated 
Table 3 Most frequently found drugs (n) in addition to venlafaxine and citalopram in the postmortem cases divided into intoxications (comprising suicide, accidents and undetermined intoxication cases) and non-intoxications (comprising all other causes of deaths not related to intoxication)

Venlafaxine positive cases

Intoxications

Non-intoxications

Intoxications

Non-intoxications

Propiomazine $^{\mathrm{a}}(18)$

Ethanol (31)

Zopiclone (15)

Mirtazapin (13)

Zopiclone (12)

Alimemazine (10)

Paracetamol (10)

Ethanol (13)

Diazepam (12)

Nordiazepam (8)
Ethanol (18)

Propiomazine $^{\mathrm{a}}$ (17)

Zopiclone (11)

Nordiazepam (6)

Paracetamol (5)
Paracetamol (19)

Ethanol (16)

Mirtazapine (7)

Alimemazine (6)

Diazepam (5)

${ }^{\text {a} P r o p i o m a z i n e ~ a n d / o r ~ d i h y d r o p r o p i o m a z i n e ~}$ 
Table 4 Genotype frequencies found in the venlafaxine positive cases $(n=116)$, the citalopram positive cases $(n=112)$ and in all cases (i.e. venlafaxine + citalopram cases, $n=228)$

\begin{tabular}{|c|c|c|c|c|c|c|c|}
\hline \multirow{3}{*}{$\begin{array}{l}\text { SNP } \\
\text { G1199A }\end{array}$} & \multirow{2}{*}{$\begin{array}{l}\text { Genotype } \\
\text { G/G }\end{array}$} & \multicolumn{2}{|c|}{$\begin{array}{l}\text { Venlafaxine } \\
\text { positive cases }\end{array}$} & \multicolumn{2}{|c|}{$\begin{array}{c}\text { Citalopram } \\
\text { positive cases }\end{array}$} & \multicolumn{2}{|c|}{ All cases } \\
\hline & & 109 & $(94 \%)$ & 108 & $(96 \%)$ & 217 & $(95 \%)$ \\
\hline & G/A & 7 & $(6 \%)$ & 4 & $(4 \%)$ & 11 & $(5 \%)$ \\
\hline \multirow[t]{3}{*}{$\mathrm{C} 1236 \mathrm{~T}^{\mathrm{a}}$} & $\mathrm{C} / \mathrm{C}$ & 45 & $(39 \%)$ & 40 & $(36 \%)$ & 85 & $(38 \%)$ \\
\hline & $\mathrm{C} / \mathrm{T}$ & 58 & $(51 \%)$ & 47 & $(42 \%)$ & 105 & $(47 \%)$ \\
\hline & $\mathrm{T} / \mathrm{T}$ & 11 & $(10 \%)$ & 24 & $(22 \%)$ & 35 & $(16 \%)$ \\
\hline \multirow[t]{5}{*}{ G2677T/A } & $\mathrm{G} / \mathrm{G}$ & 44 & $(38 \%)$ & 39 & $(35 \%)$ & 83 & $(36 \%)$ \\
\hline & $\mathrm{G} / \mathrm{T}$ & 49 & $(42 \%)$ & 40 & $(36 \%)$ & 89 & $(39 \%)$ \\
\hline & $\mathrm{T} / \mathrm{T}$ & 13 & $(11 \%)$ & 23 & $(21 \%)$ & 36 & $(16 \%)$ \\
\hline & $\mathrm{G} / \mathrm{A}$ & 3 & $(3 \%)$ & 4 & $(4 \%)$ & 7 & $(3 \%)$ \\
\hline & $\mathrm{T} / \mathrm{A}$ & 7 & $(6 \%)$ & 6 & $(5 \%)$ & 13 & $(6 \%)$ \\
\hline \multirow[t]{3}{*}{ C3435T } & $\mathrm{C} / \mathrm{C}$ & 26 & $(22 \%)$ & 23 & $(21 \%)$ & 49 & $(21 \%)$ \\
\hline & $\mathrm{C} / \mathrm{T}$ & 58 & $(50 \%)$ & 56 & $(50 \%)$ & 114 & $(50 \%)$ \\
\hline & $\mathrm{T} / \mathrm{T}$ & 32 & $(28 \%)$ & 33 & $(29 \%)$ & 65 & $(29 \%)$ \\
\hline
\end{tabular}

${ }^{\mathrm{a}}$ Genotyping for C1236T failed for two venlafaxine positive cases and one citalopram positive case.

The number (and percentage) of cases with different genotypes are displayed.

All genotypes are in Hardy-Weinberg equilibrium. 
Table 5 Genotype frequencies found in the venlafaxine and citalopram positive cases divided into intoxications (comprising suicides, accidents and undetermined intoxication cases) and non-intoxications (comprising all other causes of deaths not related to intoxication)

\begin{tabular}{|c|c|c|c|c|c|c|c|c|c|c|c|c|c|}
\hline \multirow[b]{2}{*}{ SNP } & \multirow[b]{2}{*}{ Genotype } & \multicolumn{4}{|c|}{ Venlafaxine positive cases } & \multicolumn{4}{|c|}{ Citalopram positive cases } & \multicolumn{4}{|c|}{ All cases } \\
\hline & & \multicolumn{2}{|c|}{ Intoxications } & \multicolumn{2}{|c|}{ Non-intoxications } & \multicolumn{2}{|c|}{ Intoxications } & \multicolumn{2}{|c|}{ Non-intoxications } & \multicolumn{2}{|c|}{ Intoxications } & \multicolumn{2}{|c|}{ Non-intoxications } \\
\hline \multirow[t]{4}{*}{ G1199A } & $\mathrm{G} / \mathrm{G}$ & 34 & $(94 \%)$ & 75 & $(94 \%)$ & 36 & $(97 \%)$ & 72 & $(96 \%)$ & 70 & $(96 \%)$ & 147 & $(95 \%)$ \\
\hline & $\mathrm{G} / \mathrm{A}$ & 2 & $(6 \%)$ & 5 & $(6 \%)$ & 1 & $(3 \%)$ & 3 & $(4 \%)$ & 3 & $(4 \%)$ & 8 & $(5 \%)$ \\
\hline & Total & 36 & & 80 & & 37 & & 75 & & 73 & & 155 & \\
\hline & $\mathrm{p}$-value & \multicolumn{4}{|c|}{$>0.9999$} & \multicolumn{4}{|c|}{$>0.9999$} & \multicolumn{4}{|c|}{$>0.9999$} \\
\hline \multirow[t]{4}{*}{$\mathrm{C} 1236 \mathrm{~T}$} & $\mathrm{C} / \mathrm{C}+\mathrm{C} / \mathrm{T}$ & 35 & $(100 \%)$ & 68 & $(86 \%)$ & 31 & $(84 \%)$ & 56 & $(76 \%)$ & 66 & $(92 \%)$ & 124 & $(81 \%)$ \\
\hline & $\mathrm{T} / \mathrm{T}$ & 0 & - & 11 & $(14 \%)$ & 6 & $(16 \%)$ & 18 & $(24 \%)$ & 6 & $(8 \%)$ & 29 & $(19 \%)$ \\
\hline & Total & 35 & & 79 & & 37 & & 74 & & 72 & & 153 & \\
\hline & p-value & \multicolumn{4}{|c|}{0.0173} & \multicolumn{4}{|c|}{0.4638} & \multicolumn{4}{|c|}{0.0483} \\
\hline \multirow[t]{4}{*}{ G2677T/A } & $\mathrm{G} / \mathrm{G}+\mathrm{G} / \mathrm{T}$ & 32 & $(97 \%)$ & 61 & $(84 \%)$ & 28 & $(80 \%)$ & 51 & $(76 \%)$ & 60 & $(88 \%)$ & 112 & $(80 \%)$ \\
\hline & $\mathrm{T} / \mathrm{T}$ & 1 & $(3 \%)$ & 12 & $(16 \%)$ & 7 & $(20 \%)$ & 16 & $(24 \%)$ & 8 & $(12 \%)$ & 28 & $(20 \%)$ \\
\hline & Total & 33 & & 73 & & 35 & & 67 & & 68 & & 140 & \\
\hline & $\mathrm{p}$-value & \multicolumn{4}{|c|}{0.0597} & \multicolumn{4}{|c|}{0.8042} & \multicolumn{4}{|c|}{0.1729} \\
\hline \multirow[t]{4}{*}{$\mathrm{C} 3435 \mathrm{~T}$} & $\mathrm{C} / \mathrm{C}+\mathrm{C} / \mathrm{T}$ & 32 & $(89 \%)$ & 52 & $(65 \%)$ & 28 & $(76 \%)$ & 51 & $(68 \%)$ & 60 & $(82 \%)$ & 103 & $(66 \%)$ \\
\hline & $\mathrm{T} / \mathrm{T}$ & 4 & $(11 \%)$ & 28 & $(35 \%)$ & 9 & $(24 \%)$ & 24 & $(32 \%)$ & 13 & $(18 \%)$ & 52 & $(34 \%)$ \\
\hline & Total & 36 & & 80 & & 37 & & 75 & & 73 & & 155 & \\
\hline & p-value & \multicolumn{4}{|c|}{0.0074} & \multicolumn{4}{|c|}{0.5100} & \multicolumn{4}{|c|}{0.0179} \\
\hline
\end{tabular}

The number (and percentage) of cases with different genotypes are displayed.

$\mathrm{P}<0.05$ Fishers exact test; intoxications vs. non-intoxications 
Table S1 Age, sex, venlafaxine (VEN) and O-desmethylvenlafaxine (ODV) femoral blood concentrations in relation to other found drugs and cause and manner of death.

\begin{tabular}{|c|c|c|c|c|c|c|}
\hline \multirow[b]{2}{*}{ Case } & \multirow[b]{2}{*}{$\begin{array}{l}\text { Age } \\
(\text { sex })\end{array}$} & \multicolumn{2}{|c|}{ Concentration } & \multirow[b]{2}{*}{$\begin{array}{l}\text { Other drugs in } \\
\text { femoral blood }\end{array}$} & \multirow[b]{2}{*}{$\begin{array}{l}\text { Cause of } \\
\text { death }\end{array}$} & \multirow[b]{2}{*}{$\begin{array}{l}\text { Manner of } \\
\text { death }\end{array}$} \\
\hline & & $\begin{array}{l}\text { VEN } \\
\mu \mathrm{g} / \mathrm{g}\end{array}$ & $\begin{array}{l}\text { ODV } \\
\mu g / g\end{array}$ & & & \\
\hline 1 & $71(\mathrm{M})$ & 0.1 & ND & Tramadol & Hanging & Suicide \\
\hline 2 & 24 (M) & 0.2 & 0.2 & Ethanol & Gunshot & Suicide \\
\hline 3 & $37(\mathrm{~F})$ & 0.3 & 0.5 & $\begin{array}{l}\text { Ethanol } \\
\text { Tramadol } \\
\text { Propiomazine } \\
\text { Dihydropropiomazine } \\
\text { Zolpidem } \\
\text { Zopiclone }\end{array}$ & Intoxication & Suicide \\
\hline 4 & 49 (M) & 0.4 & 0.2 & Ethanol & $\begin{array}{l}\text { Acute myocardial } \\
\text { infarction }\end{array}$ & Natural \\
\hline 5 & $41(\mathrm{~F})$ & 0.6 & 0.4 & $\begin{array}{l}\text { Ethanol } \\
\text { Mirtazapine }\end{array}$ & Hanging & Suicide \\
\hline 6 & $28(M)$ & 0.1 & 0.1 & $\begin{array}{l}\text { Ethanol } \\
\text { Diazepam } \\
\text { Nordazepam } \\
\text { Mirtazapine } \\
\text { Propiomazine } \\
\text { Dihydropropiomazine } \\
\text { Zopiclone }\end{array}$ & Intoxication & Suicide \\
\hline 7 & $51(\mathrm{~F})$ & 2.4 & 1.6 & $\begin{array}{l}\text { 7-amino-clonazepam } \\
\text { Diazepam } \\
\text { Nordazepam } \\
\text { Mirtazapine } \\
\text { Zopiclone }\end{array}$ & Hanging & Suicide \\
\hline 8 & $19(\mathrm{~F})$ & 0.3 & 0.3 & None & Hanging & Suicide \\
\hline 9 & 31 (M) & 0.7 & 0.2 & Ethanol & Hanging & Suicide \\
\hline 10 & $43(\mathrm{M})$ & 2.1 & 0.2 & $\begin{array}{l}\text { Ethanol } \\
\text { Alimemazine } \\
\text { Diazepam } \\
\text { GHB }\end{array}$ & Intoxication & Undetermined \\
\hline 11 & $59(\mathrm{M})$ & 0.7 & 0.1 & $\begin{array}{l}\text { Promethazine } \\
\text { Zopiclone }\end{array}$ & $\begin{array}{l}\text { Coronary artery } \\
\text { atherosclerosis }\end{array}$ & Natural \\
\hline 12 & $84(\mathrm{M})$ & 2 & 0.2 & None & Hanging & Suicide \\
\hline 13 & $61(\mathrm{M})$ & 1.2 & 0.5 & $\begin{array}{l}\text { Ethanol } \\
\text { Lamotrigine } \\
\text { Metoprolol } \\
\text { Mirtazapine }\end{array}$ & Hanging & Suicide \\
\hline 14 & $34(\mathrm{M})$ & 0.4 & 0.2 & $\begin{array}{l}\text { Diazepam } \\
\text { Nordazepam } \\
\text { Oxicodone } \\
\text { Propiomazine } \\
\text { Tramadol } \\
\text { Zopiclone }\end{array}$ & Intoxication & Accident \\
\hline 15 & $39(\mathrm{M})$ & 0.7 & 0.5 & $\begin{array}{l}\text { Ethanol } \\
\text { Alimemazine } \\
\text { Desmethylalimemazine }\end{array}$ & Intoxication & Accident \\
\hline 16 & $56(\mathrm{M})$ & 0.5 & 0.4 & Mirtazapine & Hanging & Suicide \\
\hline 17 & $44(\mathrm{M})$ & 0.07 & ND & $\begin{array}{l}\text { Ethanol } \\
\text { Mirtazapine } \\
\text { Desmethylmirtazapine } \\
\text { Topiramate } \\
\text { Zopiclone }\end{array}$ & Intoxication & Suicide \\
\hline 18 & $49(\mathrm{~F})$ & 0.9 & 0.4 & Bupropione & Intoxication & Suicide \\
\hline 19 & $41(\mathrm{M})$ & 0.07 & ND & None & Hanging & Suicide \\
\hline 20 & $35(\mathrm{M})$ & 0.1 & 0.2 & $\begin{array}{l}\text { Ethanol } \\
\text { Alimemazine }\end{array}$ & Hanging & Suicide \\
\hline 21 & $38(F)$ & 0.5 & 0.2 & None & Jump from hight & Suicide \\
\hline 22 & 25 (M) & 0.2 & ND & $\begin{array}{l}\text { Ethanol } \\
\text { Oxazepam }\end{array}$ & Drowning & Suicide \\
\hline $\begin{array}{l}23 \\
24\end{array}$ & $\begin{array}{l}33(\mathrm{~F}) \\
44(\mathrm{M})\end{array}$ & $\begin{array}{l}0.7 \\
0.05\end{array}$ & $\begin{array}{l}0.5 \\
0.2\end{array}$ & $\begin{array}{l}\text { Mirtazapine } \\
\text { Ethanol }\end{array}$ & $\begin{array}{l}\text { Hanging } \\
\text { Fall from hight }\end{array}$ & $\begin{array}{l}\text { Suicide } \\
\text { Accident }\end{array}$ \\
\hline 25 & $57(\mathrm{M})$ & 0.09 & 0.4 & $\begin{array}{l}\text { Ethanol } \\
\text { Alprazolam } \\
\text { Dextropropoxyphene }\end{array}$ & Intoxication & Suicide \\
\hline 26 & $56(\mathrm{~F})$ & 1.5 & 0.3 & Ethanol & Hanging & Suicide \\
\hline
\end{tabular}




\begin{tabular}{|c|c|c|c|c|c|c|}
\hline & & & & $\begin{array}{l}\text { Alimemazine } \\
\text { Paracetamol } \\
\text { Tramadol }\end{array}$ & & \\
\hline 27 & $62(\mathrm{M})$ & 0.9 & 0.5 & Ethanol & $\begin{array}{l}\text { Coronary artery } \\
\text { atherosclerosis }\end{array}$ & Natural \\
\hline 28 & $50(F)$ & 0.1 & 0.2 & None & Drowning & Accident \\
\hline 29 & $86(F)$ & 0.2 & 0.4 & None & Drowning & Suicide \\
\hline 30 & $63(F)$ & 0.08 & 0.2 & None & $\begin{array}{l}\text { Gastrointestinal } \\
\text { hemorrhage }\end{array}$ & Natural \\
\hline 31 & $48(F)$ & 0.8 & ND & $\begin{array}{l}\text { Carbamazepine } \\
\text { Alimemazine } \\
\text { Desmethylalimemazine }\end{array}$ & $\begin{array}{l}\text { Gastrointestinal } \\
\text { hemorrhage }\end{array}$ & Undetermined \\
\hline 32 & 28 (M) & 0.3 & 0.4 & Ethanol & Hanging & Suicide \\
\hline 33 & 37 (M) & 1.1 & 0.1 & $\begin{array}{l}\text { Ethanol } \\
\text { Olanzapine } \\
\text { Zopiclone }\end{array}$ & Hanging & Suicide \\
\hline 34 & $58(M)$ & 1.6 & ND & $\begin{array}{l}\text { Alprazolam } \\
\text { Moclobemide } \\
\text { Oxomoclobemide }\end{array}$ & Intoxication & Suicide \\
\hline 35 & $59(\mathrm{M})$ & 0.1 & 0.2 & Ethanol & $\begin{array}{l}\text { Coronary artery } \\
\text { atherosclerosis }\end{array}$ & Natural \\
\hline 36 & $66(F)$ & 0.2 & 0.6 & $\begin{array}{l}\text { 7-amino-nitrazepam } \\
\text { Promethazine }\end{array}$ & $\begin{array}{l}\text { Causa mortis } \\
\text { ignota }\end{array}$ & Undetermined \\
\hline 37 & $50(\mathrm{M})$ & 1.9 & 0.5 & $\begin{array}{l}\text { Alimemazine } \\
\text { Desmethylalimemazine } \\
\text { Quetiapine }\end{array}$ & $\begin{array}{l}\text { Acute myocardial } \\
\text { infarction }\end{array}$ & Natural \\
\hline 38 & $36(F)$ & 2.5 & 0.4 & $\begin{array}{l}\text { Codeine } \\
\text { Morphine } \\
\text { Promehtazine } \\
\text { Desmethylprometazine } \\
\text { lbuprophen }\end{array}$ & Intoxication & Undetermined \\
\hline 39 & $51(\mathrm{M})$ & 2.4 & 0.9 & $\begin{array}{l}\text { Diazepam } \\
\text { Nordiazepam } \\
\text { Lamotrigine } \\
\text { Mirtazapine } \\
\text { Propiomazine } \\
\text { Dihydropropiomazine } \\
\text { Quetiapine } \\
\text { Zopiclone }\end{array}$ & Intoxication & Suicide \\
\hline 40 & $47(\mathrm{M})$ & 0.09 & 0.2 & $\begin{array}{l}\text { Ethanol } \\
\text { Carbamazepine } \\
\text { THC }\end{array}$ & Road traffic fatality & Accident \\
\hline 41 & $33(\mathrm{M})$ & 0.5 & ND & $\begin{array}{l}\text { Ethanol } \\
\text { 7-amino-clonazepam } \\
\text { Amphetamine }\end{array}$ & Intoxication & Accident \\
\hline 42 & 28 (M) & 2 & 0.4 & Methadone & Intoxication & Accident \\
\hline 43 & $63(F)$ & 2.2 & 0.7 & $\begin{array}{l}\text { Ethanol } \\
\text { Lamotrigine } \\
\text { Mirtazapine } \\
\text { Desmethylmirtazapine } \\
\text { Theophylline } \\
\text { Zopiclone }\end{array}$ & $\begin{array}{l}\text { Aspiration caused } \\
\text { by drug } \\
\text { intoxication }\end{array}$ & Accident \\
\hline 44 & $43(\mathrm{M})$ & 0.4 & 0.8 & Pregabalin & Pneumonia & Natural \\
\hline 45 & $56(\mathrm{M})$ & 0.1 & ND & $\begin{array}{l}\text { Alprazolam } \\
\text { Dihydropropiomazine } \\
\text { Flupentixol } \\
\text { Nordazepam } \\
\text { Zopiclone }\end{array}$ & $\begin{array}{l}\text { Coronary artery } \\
\text { atherosclerosis }\end{array}$ & Natural \\
\hline 46 & $54(\mathrm{~F})$ & 1.4 & 0.2 & $\begin{array}{l}\text { Amitriptyline } \\
\text { Nortriptyline } \\
\text { Levomepromazine } \\
\text { Desmethyllevomepromazine } \\
\text { Mirtazapine } \\
\text { Desmethylmirtazapine } \\
\text { Propiomazine } \\
\text { Dihydropropiomazine } \\
\text { Tramadol } \\
\text { O-desmethyltramadol }\end{array}$ & Intoxication & Suicide \\
\hline 47 & $54(\mathrm{M})$ & 1.4 & 0.6 & $\begin{array}{l}\text { Diazepam } \\
\text { Nordazepam } \\
\text { Dihydropropiomazine } \\
\text { Hydroxyzine } \\
\text { Sertraline } \\
\text { Desmethylsertraline } \\
\text { Zolpidem } \\
\text { Zopiclone }\end{array}$ & Intoxication & Suicide \\
\hline
\end{tabular}




\begin{tabular}{|c|c|c|c|c|c|c|}
\hline 48 & $69(\mathrm{M})$ & 0.3 & 0.3 & $\begin{array}{l}\text { Diazepam } \\
\text { Nordazepam }\end{array}$ & Jump from hight & Suicide \\
\hline 49 & $57(\mathrm{M})$ & 0.6 & ND & $\begin{array}{l}\text { Alimemazine } \\
\text { Methadone } \\
\text { Zopiclone }\end{array}$ & Intoxication & Accident \\
\hline 50 & $45(\mathrm{M})$ & 0.2 & 0.2 & Ethanol & Stair fall & Accident \\
\hline 51 & $64(F)$ & 1.2 & 0.7 & Ethanol & $\begin{array}{l}\text { Causa mortis } \\
\text { ignota }\end{array}$ & Undetermined \\
\hline 52 & $65(\mathrm{M})$ & 0.2 & 0.4 & None & Hanging & Suicide \\
\hline 53 & $47(\mathrm{M})$ & 1.1 & ND & Ethanol & Hanging & Suicide \\
\hline 54 & $59(\mathrm{~F})$ & 0.4 & 0.7 & None & Road traffic fatality & Accident \\
\hline 55 & 50 (M) & 0.1 & 0.2 & None & Hanging & Suicide \\
\hline 56 & $49(\mathrm{M})$ & 0.4 & 0.2 & Ethanol & $\begin{array}{l}\text { Gastrointestinal } \\
\text { hemorrhage }\end{array}$ & Natural \\
\hline 57 & $52(\mathrm{~F})$ & 0.2 & 0.3 & None & $\begin{array}{l}\text { Unspecified } \\
\text { means }\end{array}$ & Suicide \\
\hline 58 & $33(\mathrm{~F})$ & 0.7 & 0.5 & Mirtazapine & Hanging & Suicide \\
\hline 59 & $63(F)$ & 5.1 & 0.6 & $\begin{array}{l}\text { Cyanide } \\
\text { Fentanyl } \\
\text { Metoprolol } \\
\text { Carbon monoxide } \\
\text { Zopiclone }\end{array}$ & Intoxication & Accident \\
\hline 60 & $32(\mathrm{~F})$ & 0.9 & ND & $\begin{array}{l}\text { Biperiden } \\
\text { Diazepam } \\
\text { Nordazepam } \\
\text { Ethylmorphine } \\
\text { Haloperidol } \\
\text { Levomepromazine } \\
\text { 7-amino-nitrazepame } \\
\text { Dihydropropiomazine } \\
\text { Zopiclone } \\
\text { Olanzapine }\end{array}$ & Intoxication & Accident \\
\hline 61 & $57(\mathrm{M})$ & 0.3 & 0.5 & $\begin{array}{l}\text { Amitriptyline } \\
\text { Diazepam } \\
\text { Nordazepam } \\
\text { Codeine } \\
\text { Morphine } \\
\text { Paracetamol }\end{array}$ & $\begin{array}{l}\text { Coronary } \\
\text { arteriosclerosis }\end{array}$ & Natural \\
\hline 62 & $24(\mathrm{M})$ & 1.2 & 0.4 & $\begin{array}{l}\text { Alimemazine } \\
\text { Lamotrigine } \\
\text { Mirtazapine } \\
\text { Desmethylmirtazapine }\end{array}$ & Hanging & Suicide \\
\hline 63 & $62(\mathrm{M})$ & 0.9 & 0.5 & Ethanol & $\begin{array}{l}\text { Coronary } \\
\text { arteriosclerosis }\end{array}$ & Natural \\
\hline 64 & $64(\mathrm{M})$ & 0.8 & 0.4 & $\begin{array}{l}\text { Biperiden } \\
\text { Carbon monoxide } \\
\text { Zopiclone }\end{array}$ & Fire & Accident \\
\hline 65 & $50(\mathrm{~F})$ & 0.1 & 0.2 & None & Drowning & Accident \\
\hline 66 & $86(\mathrm{~F})$ & 0.2 & 0.4 & None & Drowning & Suicide \\
\hline 67 & $38(F)$ & 0.2 & 0.5 & $\begin{array}{l}\text { Carbon monoxide } \\
\text { Zopiclone }\end{array}$ & Gas & Suicide \\
\hline 68 & $28(\mathrm{M})$ & 0.3 & 0.4 & Ethanol & Hanging & Suicide \\
\hline 69 & $37(\mathrm{M})$ & 1.1 & 0.1 & $\begin{array}{l}\text { Zopiclone } \\
\text { Olanzapine } \\
\text { Ethanol }\end{array}$ & Hanging & Suicide \\
\hline 70 & $26(\mathrm{M})$ & 0.4 & ND & $\begin{array}{l}\text { Alimemazine } \\
\text { THC } \\
\text { Buprenorphine } \\
\text { Mirtazapine } \\
\text { Norbuprenorphine } \\
\text { Phenazepam }\end{array}$ & Intoxication & Accident \\
\hline 71 & $58(M)$ & 1.6 & ND & $\begin{array}{l}\text { Alprazolam } \\
\text { Moclobemide } \\
\text { Oxomoclobemide }\end{array}$ & Intoxication & Suicide \\
\hline 72 & $59(\mathrm{M})$ & 0.1 & 0.2 & Ethanol & $\begin{array}{l}\text { Coronary } \\
\text { arteriosclerosis }\end{array}$ & Natural \\
\hline 73 & $31(\mathrm{M})$ & 0.6 & 0.3 & $\begin{array}{l}\text { 7-amino-clonazepam } \\
\text { Codeine } \\
\text { Methadone } \\
\text { Morphine }\end{array}$ & Hanging & Suicide \\
\hline 74 & $66(F)$ & 0.2 & 0.6 & $\begin{array}{l}\text { 7-amino-nitrazepam } \\
\text { Promethazine }\end{array}$ & Unknown & Natural \\
\hline 75 & $66(\mathrm{M})$ & 0.2 & ND & $\begin{array}{l}\text { Alimemazine } \\
\text { Dihydropropiomazine } \\
\text { Ethanol }\end{array}$ & Drowning & Suicide \\
\hline 76 & $50(\mathrm{M})$ & 1.9 & 0.5 & Alimemazine & Acute ischemic & Natural \\
\hline
\end{tabular}




\begin{tabular}{|c|c|c|c|c|c|c|}
\hline & & & & $\begin{array}{l}\text { Desmethylalimemazine } \\
\text { Quetiapine }\end{array}$ & myocardial injury & \\
\hline 77 & $36(F)$ & 2.5 & 0.4 & $\begin{array}{l}\text { Ibuprophen } \\
\text { Codeine } \\
\text { Morphine } \\
\text { Promethazine } \\
\text { Desmethylpromethazine }\end{array}$ & Intoxication & Undetermined \\
\hline 78 & $51(\mathrm{M})$ & 2.4 & 0.9 & $\begin{array}{l}\text { Diazepam } \\
\text { Nordazepam } \\
\text { Propiomazine } \\
\text { Dihydropropiomazine } \\
\text { Zopiclone } \\
\text { Quetiapine } \\
\text { Lamotrigine } \\
\text { Mirtazapine }\end{array}$ & Intoxication & Suicide \\
\hline 79 & $25(\mathrm{M})$ & 0.5 & ND & $\begin{array}{l}\text { Dextropropoxiphene } \\
\text { Diazepam } \\
\text { Nordazepam } \\
\text { Buprenorphine } \\
\text { Norbuprenorphine }\end{array}$ & Intoxication & Suicide \\
\hline 80 & $33(\mathrm{M})$ & 0.5 & ND & $\begin{array}{l}\text { Amphetamine } \\
\text { 7-amino-clonazepam } \\
\text { Ethanol }\end{array}$ & Intoxication & Accident \\
\hline 81 & $28(\mathrm{M})$ & 2 & 0.4 & Methadone & Intoxication & Accident \\
\hline 82 & $63(F)$ & 2.2 & 0.7 & $\begin{array}{l}\text { Theophylline } \\
\text { Zopiclone } \\
\text { Lamotrigine } \\
\text { Mirtazapine } \\
\text { Desmethylmirtazapine } \\
\text { Ethanol }\end{array}$ & $\begin{array}{l}\text { Obstruction of } \\
\text { respiratory tract }\end{array}$ & Accident \\
\hline 83 & $49(\mathrm{M})$ & 0.1 & ND & $\begin{array}{l}\text { Diazepam } \\
\text { Nordazepam } \\
\text { Levomepromazine } \\
\text { Desmethyllevomepromazine } \\
\text { Mirtazapine } \\
\text { Desmethylmirtazapine } \\
\text { Ethanol }\end{array}$ & Intoxication & Accident \\
\hline 84 & $43(\mathrm{M})$ & 0.4 & 0.8 & Pregabaline & Bronchopneumonia & Natural \\
\hline 85 & 85 (M) & 0.2 & 0.2 & Mirtazapine & Hanging & Suicide \\
\hline 86 & $56(\mathrm{M})$ & 0.1 & ND & $\begin{array}{l}\text { Alprazolam } \\
\text { Nordazepam } \\
\text { Flupentixol } \\
\text { Dihydropropiomazine } \\
\text { Zopiclone }\end{array}$ & $\begin{array}{l}\text { Coronary } \\
\text { arteriosclerosis }\end{array}$ & Natural \\
\hline 87 & $54(\mathrm{M})$ & 1.4 & 0.6 & $\begin{array}{l}\text { Diazepam } \\
\text { Nordazepam } \\
\text { Hydroxyzine } \\
\text { Dihydropropiomazine } \\
\text { Zopiclone } \\
\text { Zolpidem } \\
\text { Sertraline } \\
\text { Desmethylsertraline }\end{array}$ & Intoxication & Suicide \\
\hline 88 & $69(\mathrm{M})$ & 0.3 & 0.3 & $\begin{array}{l}\text { Diazepam } \\
\text { Nordazepam }\end{array}$ & Jump from hight & Suicide \\
\hline 89 & $57(\mathrm{M})$ & 0.6 & ND & $\begin{array}{l}\text { Alimemazine } \\
\text { Methadone } \\
\text { Zopiclone }\end{array}$ & Unknown & Natural \\
\hline 90 & $45(\mathrm{M})$ & 0.2 & 0.2 & None & Fall & Accident \\
\hline 91 & 64 (M) & 0.3 & 0.5 & $\begin{array}{l}\text { Paracetamol } \\
\text { Mirtazapine } \\
\text { Olanzapine }\end{array}$ & Gun shot & Undetermined \\
\hline 92 & $30(\mathrm{M})$ & 0.9 & 0.3 & $\begin{array}{l}\text { Alprazolam } \\
\text { Amphetamine } \\
\text { Methadone } \\
\text { Methamphetamine } \\
\text { Metoprolol }\end{array}$ & Intoxication & Accident \\
\hline 93 & $27(\mathrm{M})$ & 1.1 & 0.2 & $\begin{array}{l}\text { Alimemazine } \\
\text { Diazepam } \\
\text { Oxazepam } \\
\text { Propiomazine } \\
\text { Dihydropropiomazine } \\
\text { Zolpidem }\end{array}$ & Intoxication & Suicide \\
\hline 94 & $43(\mathrm{M})$ & 0.8 & 0.4 & $\begin{array}{l}\text { Zopiclone } \\
\text { Lamotrigine }\end{array}$ & Hanging & Suicide \\
\hline 95 & $79(\mathrm{M})$ & 0.3 & ND & $\begin{array}{l}\text { Alprazolam } \\
\text { Cocaine }\end{array}$ & Fall & Undetermined \\
\hline
\end{tabular}




\begin{tabular}{|c|c|c|c|c|c|c|}
\hline & & & & $\begin{array}{l}\text { Bensoylecgonine } \\
\text { Paracetamol } \\
\text { Ethanol }\end{array}$ & & \\
\hline 96 & $69(\mathrm{~F})$ & 0.8 & 0.4 & $\begin{array}{l}\text { Diazepam } \\
\text { Nordazepam } \\
\text { Paracetamol } \\
\text { Mirtazapine } \\
\text { Desmethylmirtazapine }\end{array}$ & $\begin{array}{l}\text { Old myocardial } \\
\text { infarction }\end{array}$ & Natural \\
\hline 97 & $49(\mathrm{M})$ & 0.6 & ND & $\begin{array}{l}\text { Alimemazine } \\
\text { Nordazepam } \\
\text { Hydroxizine } \\
\text { Promethazine } \\
\text { Desmethylpromethazine } \\
\text { Ethanol }\end{array}$ & Hanging & Suicide \\
\hline 98 & $53(\mathrm{M})$ & 0.4 & 0.3 & Ethanol & $\begin{array}{l}\text { Intracerebral } \\
\text { hemorrhage }\end{array}$ & Natural \\
\hline 99 & $47(\mathrm{~F})$ & 1.1 & 0.6 & $\begin{array}{l}\text { Cyanide } \\
\text { Carbon monoxide } \\
\text { Mianserine } \\
\text { Desmethylmianserine } \\
\text { Ethanol }\end{array}$ & Intoxication & Accident \\
\hline 100 & $38(\mathrm{M})$ & 0.6 & 0.2 & $\begin{array}{l}\text { Alimemazine } \\
\text { Zopiclone } \\
\text { Pregabaline }\end{array}$ & Intoxication & Accident \\
\hline 101 & $62(\mathrm{~F})$ & 0.2 & 0.3 & Ethanol & & Suicide \\
\hline 102 & $43(\mathrm{M})$ & 0.2 & 0.8 & $\begin{array}{l}\text { Diazepam } \\
\text { Nordazepam } \\
\text { Ephedrine } \\
\text { Ethylmorphine } \\
\text { Morphine } \\
\text { Paracetamol }\end{array}$ & Bronchopneumonia & Natural \\
\hline 103 & $18(\mathrm{~F})$ & 0.2 & 0.4 & $\begin{array}{l}\text { Methadone } \\
\text { Zopiclone } \\
\text { Ethanol }\end{array}$ & Intoxication & Accident \\
\hline 104 & $50(\mathrm{M})$ & 0.3 & 0.2 & $\begin{array}{l}\text { Diazepam } \\
\text { THC } \\
\text { Ethanol }\end{array}$ & Intoxication & Suicide \\
\hline 105 & $56(F)$ & 0.5 & 0.6 & $\begin{array}{l}\text { Amitriptyline } \\
\text { Carbon monoxide } \\
\text { Paracetamol } \\
\text { Pregabalin } \\
\text { Ethanol }\end{array}$ & Excessive heat & Accident \\
\hline 106 & $84(F)$ & 1.8 & 0.9 & $\begin{array}{l}\text { Paracetamol } \\
\text { Tamoxiphen } \\
\text { Ethanol }\end{array}$ & $\begin{array}{l}\text { Coronary } \\
\text { arteriosclerosis }\end{array}$ & Natural \\
\hline 107 & $59(\mathrm{~F})$ & 1.1 & 0.4 & None & Drowning & Suicide \\
\hline 108 & $40(F)$ & 0.5 & 1 & $\begin{array}{l}\text { Alprazolam } \\
\text { Codeine } \\
\text { Mophine } \\
\text { 7-amino-nitrazepam } \\
\text { Paracetamol } \\
\text { Zopiclone } \\
\text { Quetiaphine } \\
\text { Ethanol }\end{array}$ & Intoxication & Accident \\
\hline 109 & $66(F)$ & 0.3 & 0.4 & None & Hanging & Suicide \\
\hline 110 & $25(\mathrm{M})$ & 0.6 & 0.3 & $\begin{array}{l}\text { Alimemazine } \\
\text { Desmethylalimemazine } \\
\text { Propiomazine } \\
\text { Dihydropropiomazine } \\
\text { Zopiclone } \\
\text { Desmethylsertraline }\end{array}$ & Intoxication & Suicide \\
\hline 111 & $73(F)$ & 0.5 & 0.3 & $\begin{array}{l}\text { Alimemazine } \\
\text { Desmethylalimemazine } \\
\text { Olanzapine } \\
\text { Reboxetine }\end{array}$ & Drowning & Suicide \\
\hline 112 & $66(\mathrm{M})$ & 0.1 & 0.2 & Paracetamol & $\begin{array}{l}\text { Intracerebral } \\
\text { hemorrhage }\end{array}$ & Natural \\
\hline 113 & $44(F)$ & 6.6 & ND & $\begin{array}{l}\text { Amitriptyline } \\
\text { Dextropropoxyphene } \\
\text { Ethylmorphine } \\
\text { Carisoprodol } \\
\text { Codeine } \\
\text { Morphine } \\
\text { Paracetamol }\end{array}$ & Intoxication & Suicide \\
\hline 114 & $58(\mathrm{~F})$ & 0.2 & 0.2 & Paracetamol & Hanging & Suicide \\
\hline 115 & $44(\mathrm{~F})$ & 0.1 & 0.1 & Mirtazapine & Intracerebral & Natural \\
\hline
\end{tabular}


M, male; F, female; VEN, venlafaxine; ODV, O-desmethylvenlafaxine; GHB, gammahydroxybutyrate; THC, tetrahydrocannabinol; ND, not detected. 
Table S2 Age, sex, citalopram (CIT) and desmethylcitalopram (DCIT) femoral blood concentrations in relation to other found drugs and cause and manner of death.

\begin{tabular}{|c|c|c|c|c|c|c|}
\hline \multirow[b]{2}{*}{ Case } & \multirow[b]{2}{*}{$\begin{array}{l}\text { Age } \\
\text { (sex) }\end{array}$} & \multicolumn{2}{|c|}{ Concentration } & \multirow[b]{2}{*}{$\begin{array}{l}\text { Other drugs in } \\
\text { femoral blood }\end{array}$} & \multirow[b]{2}{*}{$\begin{array}{l}\text { Cause of } \\
\text { death }\end{array}$} & \multirow[b]{2}{*}{$\begin{array}{l}\text { Manner of } \\
\text { death }\end{array}$} \\
\hline & & $\begin{array}{r}\text { CIT } \\
\mu g / g\end{array}$ & $\begin{array}{l}\text { DCIT } \\
\mu \mathrm{g} / \mathrm{g}\end{array}$ & & & \\
\hline 1 & $66(M)$ & 8.4 & 0.4 & Carbon monoxide & Intoxication & Suicide \\
\hline 2 & $65(\mathrm{M})$ & 0.6 & 0.1 & $\begin{array}{l}\text { Nortriptyline } \\
\text { Diazepam } \\
\text { Nordazepam } \\
\text { Tramadol } \\
\text { O-desmethyltramadol } \\
\text { Caffeine } \\
\text { Paracetamol }\end{array}$ & Cardiosclerosis & Natural \\
\hline 3 & $71(F)$ & 0.3 & 0.1 & Zopiclone & Hanging & Suicide \\
\hline 4 & $86(F)$ & 0.3 & 0.2 & $\begin{array}{l}\text { Nortriptyline } \\
\text { 7-amino-nitrazepam }\end{array}$ & Intoxication & Suicide \\
\hline 5 & $63(\mathrm{M})$ & 0.6 & 0.1 & Ethanol & Vitium cordis & Undetermined \\
\hline 6 & $59(\mathrm{~F})$ & 0.5 & 0.1 & $\begin{array}{l}\text { Ethanol } \\
\text { Oxazepam } \\
\text { 7-amino-flunitrazepam } \\
\text { Alimemazine } \\
\text { Desmethylalimemazine } \\
\text { Codeine } \\
\text { Carisoprodol } \\
\text { Meprobamate } \\
\text { Paracetamol }\end{array}$ & Corpus alienum & Accident \\
\hline 7 & $57(\mathrm{M})$ & 0.2 & 0.1 & None & $\begin{array}{l}\text { Acute ischemic } \\
\text { myocardial lesion }\end{array}$ & Natural \\
\hline 8 & $22(\mathrm{~F})$ & 0.2 & 0.1 & None & Hanging & Suicide \\
\hline 9 & $36(F)$ & 0.2 & 0.1 & $\begin{array}{l}\text { Topiramate } \\
\text { Levetiracetam }\end{array}$ & Epilepsy & Natural \\
\hline 10 & $47(\mathrm{M})$ & 1 & 0.1 & $\begin{array}{l}\text { Nitrazepam } \\
\text { 7-amino-nitrazepam } \\
\text { Alprazolam }\end{array}$ & Intoxication & Suicide \\
\hline 11 & $84(\mathrm{M})$ & 0.7 & 0.3 & $\begin{array}{l}\text { Dextropropoxyphene } \\
\text { Clomethiazole } \\
\text { Paracetamol }\end{array}$ & Burns & Accident \\
\hline 12 & $46(\mathrm{M})$ & 0.5 & ND & Nortriptyline & Intoxication & Suicide \\
\hline 13 & $84(\mathrm{M})$ & 0.3 & 0.1 & $\begin{array}{l}\text { O-desmethyltramadol } \\
\text { Paracetamol }\end{array}$ & Skull fracture & Accident \\
\hline 14 & $71(\mathrm{M})$ & 0.1 & ND & None & Peritonitis & Natural \\
\hline 15 & $54(\mathrm{M})$ & 0.4 & 0.2 & $\begin{array}{l}\text { Ethanol } \\
\text { Carbon monoxide }\end{array}$ & Intoxication & Accident \\
\hline 16 & $54(F)$ & 0.05 & ND & $\begin{array}{l}\text { Ethanol } \\
\text { Propiomazine } \\
\text { Dihydropropiomazine } \\
\text { 7-amino-flunitrazepam }\end{array}$ & Intoxication & Suicide \\
\hline 17 & $59(\mathrm{~F})$ & 0.3 & 0.2 & None & $\begin{array}{l}\text { Bleeding gastric } \\
\text { ulcer }\end{array}$ & Natural \\
\hline 18 & $55(\mathrm{M})$ & 0.6 & 0.1 & Ethanol & Cardiac disease & Natural \\
\hline 19 & $65(\mathrm{~F})$ & 1 & 0.2 & None & Hanging & Suicide \\
\hline 20 & $37(\mathrm{M})$ & 1.2 & 0.4 & $\begin{array}{l}\text { Ethanol } \\
\text { Mianserine } \\
\text { Desmethylmianserine } \\
\text { Diazepam } \\
\text { Nordazepam } \\
\text { Caffeine } \\
\text { Paracetamol }\end{array}$ & Hanging & Suicide \\
\hline 21 & $61(\mathrm{M})$ & 0.3 & 0.1 & None & Hanging & Suicide \\
\hline 22 & $62(F)$ & 0.08 & ND & Ethanol & Intoxication & Accident \\
\hline 23 & $74(\mathrm{M})$ & 0.3 & 0.1 & None & $\begin{array}{l}\text { Cardiosclerosis } \\
\text { and extreme cold }\end{array}$ & Accident \\
\hline 24 & $77(F)$ & 0.9 & 0.1 & $\begin{array}{l}\text { Carbon monoxide } \\
\text { Zopiclone }\end{array}$ & Intoxication & Accident \\
\hline 25 & $29(\mathrm{M})$ & 0.4 & 0.1 & $\begin{array}{l}\text { Ethanol } \\
\text { Alimemazine } \\
\text { Desmethylalimemazine } \\
\text { Carbamazepine } \\
\text { Hydroxyzine }\end{array}$ & Intoxication & Suicide \\
\hline 26 & $82(\mathrm{M})$ & 0.7 & 0.2 & None & Fat embolism & Accident \\
\hline 27 & $63(\mathrm{M})$ & 0.4 & 0.2 & None & Acute myocardial & Natural \\
\hline
\end{tabular}




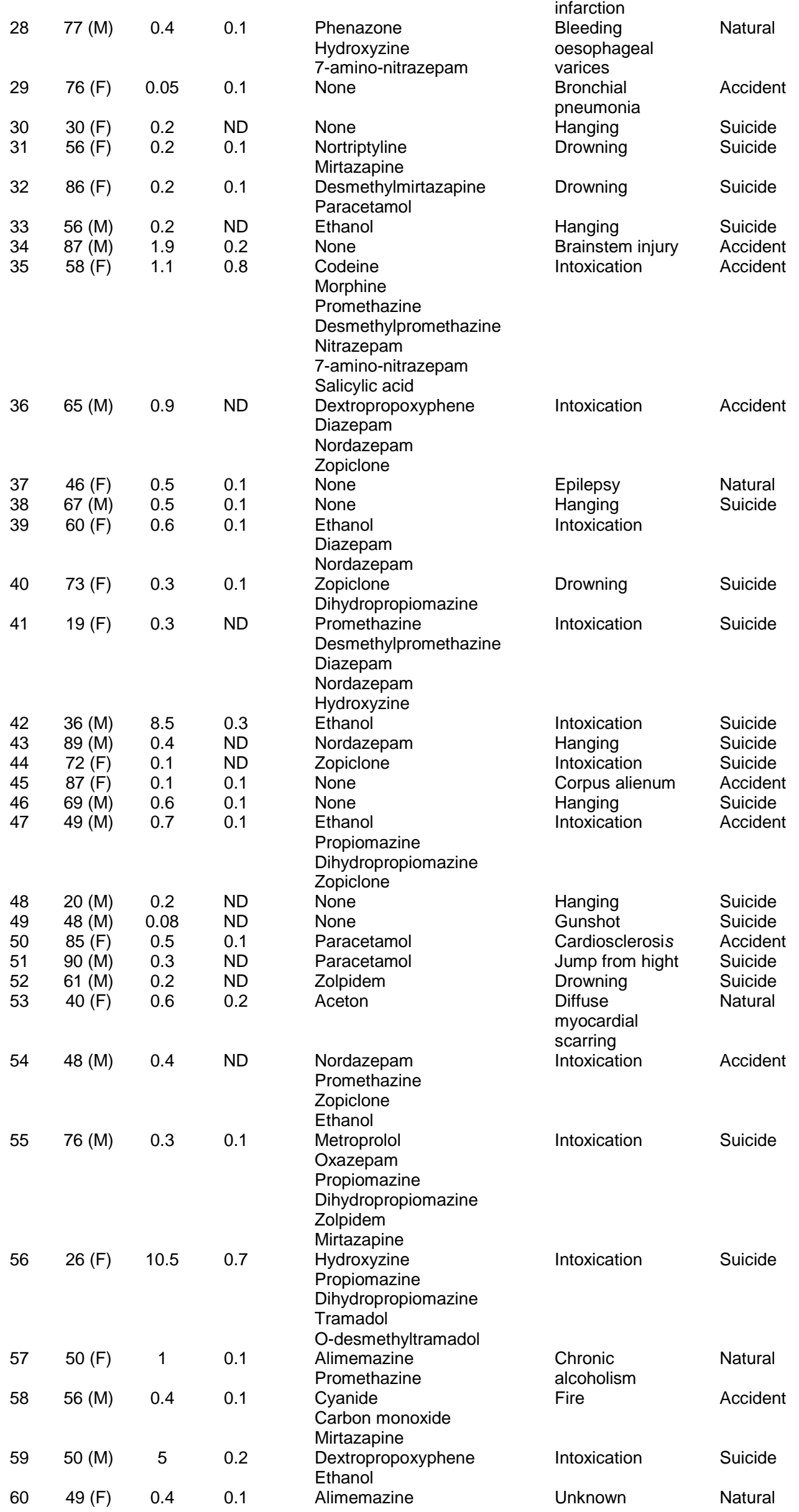




\begin{tabular}{|c|c|c|c|c|c|c|}
\hline & & & & $\begin{array}{l}\text { Hydroxyzine } \\
\text { Zolpidem }\end{array}$ & & \\
\hline 61 & $62(F)$ & 0.6 & 0.2 & $\begin{array}{l}\text { Buspiron } \\
\text { Mirtazapine }\end{array}$ & Lung emphysema & Natural \\
\hline 62 & $84(\mathrm{~F})$ & 0.2 & 0.1 & $\begin{array}{l}\text { Desmethylmirtazapine } \\
\text { None }\end{array}$ & Thrombosis/embo & Natural \\
\hline & & & & & $\begin{array}{l}\text { lus in cerebral } \\
\text { ateries }\end{array}$ & \\
\hline 63 & $37(F)$ & 0.3 & ND & $\begin{array}{l}\text { Methadone } \\
\text { Zopiclone }\end{array}$ & Intoxication & Suicide \\
\hline & & & & Olanzapine & & \\
\hline 64 & $57(\mathrm{M})$ & 0.4 & ND & $\begin{array}{l}\text { Paracetamol } \\
\text { Propiomazine } \\
\text { Dihydropropiomazine } \\
\text { Zopiclone } \\
\text { Tramadol }\end{array}$ & Intoxication & Accident \\
\hline 65 & $54(\mathrm{M})$ & 1 & 0.2 & $\begin{array}{l}\text { Methadone } \\
\text { Paracetamol } \\
\text { Mirtazapine } \\
\text { Desmethylmirtazapine }\end{array}$ & $\begin{array}{l}\text { Coronary } \\
\text { arteriosclerosis }\end{array}$ & Natural \\
\hline 66 & $87(\mathrm{M})$ & 0.4 & 0.1 & Paracetamol & Hanging & Suicide \\
\hline 67 & $74(F)$ & 1.4 & 0.2 & $\begin{array}{l}\text { Dihydropropiomazine } \\
\text { Ethanol }\end{array}$ & Suffocation & Accident \\
\hline 68 & $55(\mathrm{M})$ & 0.3 & ND & Ethanol & Drowning & Accident \\
\hline 69 & $74(\mathrm{M})$ & 0.4 & 0.3 & $\begin{array}{l}\text { Diazepam } \\
\text { Nordazepam } \\
\text { Ethylmorphine } \\
\text { Morphine } \\
\text { Mianserine }\end{array}$ & Intoxication & Accident \\
\hline 70 & $27(\mathrm{M})$ & 0.7 & 0.2 & $\begin{array}{l}\text { Buprenorphine } \\
\text { Norbuprenorphine } \\
\text { Ethanol }\end{array}$ & Intoxication & Accident \\
\hline 71 & $59(\mathrm{M})$ & 0.3 & 0.1 & $\begin{array}{l}\text { Diazepam } \\
\text { Nordazepam }\end{array}$ & Rectal cancer & Natural \\
\hline 72 & $51(\mathrm{M})$ & 0.3 & ND & Alimemazine & Drowning & Accident \\
\hline 73 & $49(F)$ & 0.9 & 0.1 & $\begin{array}{l}\text { Prometazine } \\
\text { Ethanol }\end{array}$ & Intoxication & Undetermined \\
\hline 74 & $74(\mathrm{M})$ & 0.5 & 0.1 & $\begin{array}{l}\text { Diazepam } \\
\text { Nordazepam } \\
\text { Metoprolol } \\
\text { Ethanol }\end{array}$ & $\begin{array}{l}\text { Obstruction of } \\
\text { respiratory tract }\end{array}$ & Accident \\
\hline 75 & $72(F)$ & 1.3 & 0.2 & Paracetamol & $\begin{array}{l}\text { Thrombosis/embo } \\
\text { lus in cerebral } \\
\text { ateries }\end{array}$ & Natural \\
\hline 76 & $76(\mathrm{M})$ & 0.6 & 0.1 & $\begin{array}{l}\text { Carbon monoxide } \\
\text { Zopoiclone } \\
\text { Ethanol }\end{array}$ & Gas & Suicide \\
\hline 77 & $82(\mathrm{M})$ & 0.3 & 0.1 & None & Traffic & Accident \\
\hline 78 & $60(F)$ & 0.7 & 0.3 & $\begin{array}{l}\text { Paracetamol } \\
\text { Zopiclone } \\
\text { Ethanol }\end{array}$ & Intoxication & Undetermined \\
\hline 79 & $38(\mathrm{M})$ & 4.7 & 0.2 & $\begin{array}{l}\text { Alimemazine } \\
\text { Desmethylalimemazine } \\
\text { Alprazolam } \\
\text { Ketamine } \\
\text { Metoprolol } \\
\text { Zopiclone }\end{array}$ & Intoxication & Suicide \\
\hline 80 & $51(\mathrm{~F})$ & 0.3 & ND & $\begin{array}{l}\text { Metoclopramide } \\
\text { Lidocaine } \\
\text { Morphine } \\
\text { Paracetamol }\end{array}$ & Sepsis & Natural \\
\hline 81 & $74(\mathrm{M})$ & 0.2 & ND & Phenytoin & Hanging & Suicide \\
\hline 82 & $57(\mathrm{M})$ & 0.8 & 0.2 & None & $\begin{array}{l}\text { Old myocardial } \\
\text { infarction }\end{array}$ & Natural \\
\hline 83 & $56(\mathrm{M})$ & 0.6 & ND & Ethanol & Hanging & Suicide \\
\hline 84 & $65(F)$ & 0.3 & ND & $\begin{array}{l}\text { Flecainide } \\
\text { Ethanol }\end{array}$ & Intoxication & Undetermined \\
\hline 85 & $49(\mathrm{M})$ & 0.5 & 0.1 & $\mathrm{THC}$ & Unknown & Natural \\
\hline 86 & $42(\mathrm{M})$ & 1.1 & 0.1 & $\begin{array}{l}\text { Alimemazine } \\
\text { Desmethylalimemazine } \\
\text { Metoprolol } \\
\text { Zolpidem } \\
\text { Ethanol } \\
\text { Promethazine } \\
\text { Desmethylpromethazine }\end{array}$ & Cardiomegaly & Natural \\
\hline
\end{tabular}




\begin{tabular}{|c|c|c|c|c|c|c|}
\hline 87 & $64(F)$ & 0.2 & ND & $\begin{array}{l}\text { Acetone } \\
\text { Hydroxyzine } \\
\text { Dihydropropiomazine }\end{array}$ & $\begin{array}{l}\text { Chronic } \\
\text { myocardial } \\
\text { ischemia }\end{array}$ & Natural \\
\hline 88 & $72(\mathrm{M})$ & 0.5 & 0.1 & Dihydropropiomazine & Intoxication & Suicide \\
\hline 89 & $78(\mathrm{~F})$ & 0.3 & 0.1 & $\begin{array}{l}\text { Diazepam } \\
\text { Paracetamol } \\
\text { Zopiclone } \\
\text { Ethanol }\end{array}$ & Drowning & Suicide \\
\hline 90 & $46(\mathrm{M})$ & 0.2 & ND & $\begin{array}{l}\text { Propiomazine } \\
\text { Dihydropropiomazine } \\
\text { Ethanol }\end{array}$ & Intoxication & Undetermined \\
\hline 91 & $47(\mathrm{M})$ & 0.3 & 0.1 & Carbon monoxide & Gas & Suicide \\
\hline 92 & $84(F)$ & 0.2 & ND & $\begin{array}{l}\text { Paracetamol } \\
\text { Tramadol }\end{array}$ & $\begin{array}{l}\text { Coronary } \\
\text { arteriosclerosis }\end{array}$ & Natural \\
\hline 93 & $88(M)$ & 0.4 & 0.1 & $\begin{array}{l}\text { Norverapamil } \\
\text { Verapamil }\end{array}$ & Hanging & Suicide \\
\hline 94 & $51(\mathrm{M})$ & 0.3 & ND & $\begin{array}{l}\text { Morphine } \\
\text { Duloxetine } \\
\text { Metphormine } \\
\text { Ethanol }\end{array}$ & Intoxication & Undetermined \\
\hline 95 & $46(\mathrm{M})$ & 0.8 & 0.1 & $\begin{array}{l}\text { Dextropropoxyphene } \\
\text { Paracetamol } \\
\text { Zopiclone }\end{array}$ & Cardiomyopathy & Natural \\
\hline 96 & $66(M)$ & 0.5 & 0.1 & None & $\begin{array}{l}\text { Injury by } \\
\text { unspecified } \\
\text { means }\end{array}$ & Undetermined \\
\hline 97 & $40(\mathrm{M})$ & 2.4 & 0.2 & $\begin{array}{l}\text { Cocaine } \\
\text { Benzoylecgonine }\end{array}$ & Falling from hight & Undetermined \\
\hline 98 & $46(\mathrm{M})$ & 0.5 & 0.1 & $\begin{array}{l}\text { Alimemazine } \\
\text { Desmethylalimemazine } \\
\text { Dextropropoxyphene } \\
\text { Morphine } \\
\text { Paracetamol } \\
\text { Promethazine } \\
\text { Desmethylpromethazine } \\
\text { Zopiclone }\end{array}$ & Intoxication & Accident \\
\hline 99 & $26(\mathrm{M})$ & 0.2 & 0.1 & Lamotrigine & Hanging & Suicide \\
\hline 100 & $81(\mathrm{~F})$ & 0.7 & 0.1 & $\begin{array}{l}\text { Phenytoin } \\
\text { Mianserine } \\
\text { Desmethylmianserine } \\
\text { Paracetamol } \\
\text { Propiomazine } \\
\text { Dihydropropiomazine }\end{array}$ & Intoxication & Suicide \\
\hline 101 & $61(\mathrm{M})$ & 0.2 & ND & Ethanol & Intoxication & Accident \\
\hline 102 & $43(\mathrm{M})$ & 0.2 & 0.1 & Ethanol & Drowning & Accident \\
\hline 103 & $64(\mathrm{M})$ & 0.5 & 0.2 & None & $\begin{array}{l}\text { Intracerebral } \\
\text { hemorrhage }\end{array}$ & Natural \\
\hline 104 & $59(\mathrm{~F})$ & 0.2 & 0.1 & $\begin{array}{l}\text { Paracetamol } \\
\text { Mirtazapine }\end{array}$ & $\begin{array}{l}\text { Acute ischemic } \\
\text { myocardial injury }\end{array}$ & Natural \\
\hline 105 & $58(M)$ & 0.3 & 0.1 & $\begin{array}{l}\text { Mirtazapine } \\
\text { Ethanol }\end{array}$ & $\begin{array}{l}\text { Pulmonary } \\
\text { embolsim }\end{array}$ & Natural \\
\hline 106 & $53(\mathrm{~F})$ & 0.3 & 0.1 & $\begin{array}{l}\text { Paracetamol } \\
\text { Zolpidem } \\
\text { Ethanol }\end{array}$ & Intoxication & Suicide \\
\hline 107 & $77(\mathrm{~F})$ & 0.5 & 0.1 & Paracetamol & Hanging & Suicide \\
\hline 108 & $58(\mathrm{M})$ & 0.9 & ND & $\begin{array}{l}\text { Alprazolam } \\
\text { Moclobemide } \\
\text { Oxomoclobemide }\end{array}$ & Intoxication & Suicide \\
\hline 109 & $56(\mathrm{~F})$ & 1 & 0.2 & $\begin{array}{l}\text { Metoclopramide } \\
\text { Paracetamol } \\
\text { Tramadol } \\
\text { Ethanol }\end{array}$ & $\begin{array}{l}\text { Obstruction of } \\
\text { respiratory tract }\end{array}$ & Accident \\
\hline 110 & $71(\mathrm{M})$ & 0.2 & ND & Paracetamol & Gunshot & Suicide \\
\hline 111 & $47(\mathrm{M})$ & 0.6 & 0.1 & $\begin{array}{l}\text { Acetone } \\
\text { Alimemazine } \\
\text { Metoclopramide } \\
\text { Mirtazapine }\end{array}$ & $\begin{array}{l}\text { Diabetes mellitus } \\
\text { with hyperosmolar } \\
\text { coma }\end{array}$ & Natural \\
\hline 112 & $55(\mathrm{~F})$ & 0.3 & 0.1 & $\begin{array}{l}\text { Nordazepam } \\
\text { Propiomazine } \\
\text { Dihydropropiomazine } \\
\text { Zopiclone } \\
\text { Mirtazapine } \\
\text { Desmethylmirtazapine } \\
\text { Ethanol }\end{array}$ & Intoxication & Accident \\
\hline
\end{tabular}


M, male; F, female; CIT, citalopram; DCIT, desmethylcitalopram; THC, tetrahydrocannabinol; ND, not detected. 